\title{
Environmental loadings of long term sulphur storage: processes and controls
}

\author{
Cheema T.* \\ Department of Hydrogeology, Faculty of Earth Sciences, King Abdulaziz University, PO Box 80206, Jeddah 21589, Saudi Arabia \\ Received: 28/08/2016, Accepted: 30/11/2016, Available online: 05/10/2017 \\ *to whom all correspondence should be addressed: tcheema@kau.edu.sa
}

\begin{abstract}
Elemental sulphur $\left(\mathrm{S}^{\circ}\right)$ is produced at petroleum refineries as a byproduct and a decrease in $S^{\circ}$ prices has forced tens of mega-tonnes of $\mathrm{S}^{\circ}$ to be stockpiled at industrial sites. However, long-term storage of $S^{\circ}$ blocks poses a potential for contamination of surface water and groundwater because of the oxidation of $\mathrm{S}^{\circ}$ to $\mathrm{H}_{2} \mathrm{SO}_{4}$. Two key controls on the environmental loadings of $S^{\circ}$ blocks are the availability of oxygen and temperature.
\end{abstract}

Three large scale $\mathrm{S}^{\circ}$ pilot blocks were constructed to evaluate the effects of controlling factors on the oxidation of $\mathrm{S}^{\circ}$ blocks and to test the effectiveness of cover technologies. One pilot block was left exposed to the environment while two others were covered with cover material of various thicknesses to keep the underlying $S^{\circ}$ blocks either insulated or saturated. $S^{\circ}$ block temperature, availability of oxygen and drainage water chemistry data were measured over a period of three years.

The analysis of $S^{\circ}$ pilot block data indicates that the pilot blocks would serve as useful analogues to commercial scale blocks. Pilot blocks temperature and oxygen profiles with depth indicate that the selected cover material could not control the temperature and the ingress of oxygen within the $S^{\circ}$ blocks below the oxidation reaction. As a result, environmental loadings would remain a concern for the above ground sulphur storage sites.

Keywords: Pilot Sulphur Blocks. Instrumentation. Laboratory Analysis. Oxidation. Temperature.

\section{Introduction}

Sulphur is the most abundant element in petroleum after carbon and hydrogen (Payzant et al., 1986). Generally, sulfur occurs as hydrogen sulfide, organic sulfide and disulfide, benzothiophene, dibenzothiophene and their alkylated derivatives in petroleum (Speight, 2002). The presence of sulfur in petroleum is very undesirable because of sulphur corrosive nature, deleterious effects on color, unfavorable influence on antiknock and oxidation characteristics (Duissenov, 2012). Therefore, it is separated from the crude oil through desulfurazation processes at high temperature and pressure thus forming elemental sulphur $\left(\left(\mathrm{S}^{\circ}\right)\right.$. During this process, it is estimated that as high as $8 \mathrm{kgs}$ of $\mathrm{S}^{\circ}$ per barrel of oil is produced (Bonstrom, 2007). A decrease in $S^{0}$ prices has forced tens of megatonnes of $S^{0}$ to be stockpiled at industrial sites. These sites are located in northern Canada, the Middle East, and the Caspian Sea regions. However, worldwide $S^{\circ}$ storage research is neglible (Ober, 2000).

Elemental sulphur blocks are prepared by placing the molten sulfur $\left(135^{\circ} \mathrm{C}\right.$ to $\left.145^{\circ} \mathrm{C}\right)$ in small fraction of liftss $(0.1 \mathrm{~m})$ on already prepared surface of compacted clay of permeability of less than $1 \times 10^{-8} \mathrm{~m} / \mathrm{sec}$ (Bonstrom, 2007). The molten $\mathrm{S}^{\circ}$ in these lifts solidifies (at $115^{\circ} \mathrm{C}$ ), and as subsequent lifts of $\mathrm{S}^{\circ}$ are poured, a large $\mathrm{S}^{\circ}$ commercial scale block of $>1 \times 10^{5} \mathrm{~m}^{3}$ is constructed. The process of condensation converts the molten sulfur to monoclinic crystal form. With the passage of time the monoclinic sulfur converts to more stable orthorhombic sulfur. During this solidification and mineral change process, $12.5 \%$ volume shrinkage occurs thus giving rise to extensive fracturing of $S^{\circ}$ blocks (Bonstorm, 2007) that allows water to percolate and causes oxidation of $\mathrm{S}^{\circ}$ to $\mathrm{H}_{2} \mathrm{SO}_{4}$. Therefore, long term storage of $\mathrm{S}^{\circ}$ poses a potential for contamination of groundwater and surface water.

The oxidation reaction of $S^{0}$ is zero order kinetic reaction (Birkham et al., 2009; Slaton et al., 2001). $\mathrm{S}^{0}$ oxidizes to $\mathrm{SO}_{4}^{-2}$ when exposed to molecular oxygen and water in two step reaction as defined by Lloyd (1967). Sulfite $\left(\mathrm{SO}_{3}^{-2}\right)$ is an important intermediate produced in the reaction, which further oxidizes to $\mathrm{SO}_{4}^{-2}$. With the passage of time, the $\mathrm{SO}_{4}^{-2}$ concentration increases and $\mathrm{pH}$ decreases from 4.5 to 5.5 . The rate of change of $\mathrm{pH}(\mathrm{dPH} / \mathrm{dt})$ approaches to the range 1-1.5 and continue to decrease until the value of 0.8 and no further decrease in $\mathrm{pH}$. In the oxidation reaction, $\mathrm{SO}_{4}^{-2}$ combines with the hydronium ion $\left(\mathrm{H}^{+}\right)$and produces sulfuric acid $\left(\mathrm{H}_{2} \mathrm{SO}_{4}\right)$. The overall reaction for the production of $\mathrm{H}_{2} \mathrm{SO}_{4}$ is given below:

$$
\begin{aligned}
& \mathrm{S}^{0}+\mathrm{H}_{2} \mathrm{O}+\mathrm{O}_{2} \rightarrow \mathrm{SO}_{3}^{-2}+2 \mathrm{H}^{+} \\
& \mathrm{SO}_{3}^{-2}+1 / 2 \mathrm{O}_{2} \rightarrow \mathrm{SO}_{4}^{-2} \\
& \mathrm{~S}^{0}+\mathrm{H}_{2} \mathrm{O}+3 / 2 \mathrm{O}_{2} \rightarrow \mathrm{H}_{2} \mathrm{SO}_{4}
\end{aligned}
$$


The rate of oxidation depends on temperature and the availability for oxygen, nutrients and surface area (Jansen, 1984; Laishley et al., 1985). Most of this work was conducted under conrolled laboratory conditions for the purpose of crop fertilization (Janzen and Bettany, 1987). Birkham et al. (2010) studied the rates and contol of acid producton in commercial scale above ground sulphur blocks and made recommendations to reduce or control the rate of oxidation in $\mathrm{S}^{0}$ blocks. Two of the recommendations made by Birkham et al., (2010) were to maintain blocks at low temperature $\left(<5^{\circ} \mathrm{C}\right)$ and to limit the supply of oxygen to $\mathrm{S}^{0}$ blocks. However, Birkham et al., (2010) were unable to recommend as to how this could be achieved in real situation.

The objective of the current study is to design a methodology to maintain the $S^{0}$ block at low temperatures and to reduce the ingress of oxygen so that the oxidation of $\mathrm{S}^{0}$ could be minimized. The underlining guiding principle is to investigate options for acceptable long-term above ground storage of $\mathrm{S}^{0}$ by following a multi-track approach. This approach utilizes existing cover and liner technologies from the landfill and mining industry and develops the understanding of the environmental loadings of $S^{0}$ blocks.
The research program is based upon the data collected from pilot $\mathrm{S}^{0}$ blocks

\section{Material and Methods}

\section{Pilot Sulphur Blocks}

Three pilot $\mathrm{S}^{0}$ blocks $(21.3 \mathrm{~m}(\mathrm{~W}) \times 21.3 \mathrm{~m}(\mathrm{~L}) \times 2.9 \mathrm{~m}(\mathrm{H}))$ were constructed in 2005, at the Syncrude Canada Ltd. (SCL) Mildred Lake oilsands mine site (570223.00 N, $11139316.96 \mathrm{~W}$ ). The purpose was to evaluate the effect of soil cover to maintain $\mathrm{S}^{0}$ blocks at low temperature and to minimize the ingress of oxgen so that acid production associated with $S^{0}$ blocks could be reduced. Figure 1 is a cross section of one of the pilot blocks (Exposed Block). Each block has a similar liner design consisting of a fluvial Pleistocene (Pf) sand underdrain over an HDPE liner, over a compacted clay foundation. The liner system was constructed vertically up the sides of each block. The objective was to ensure that meteoric water incident to the top of the block migrated vertically downward and was captured at the base in the underdrain sand, and then collected through a series of pipes and sumps. All blocks, except the Saturated Block, have an in-ground $1893 \mathrm{~L}$ fiberglass tank to collect percolate from the block.

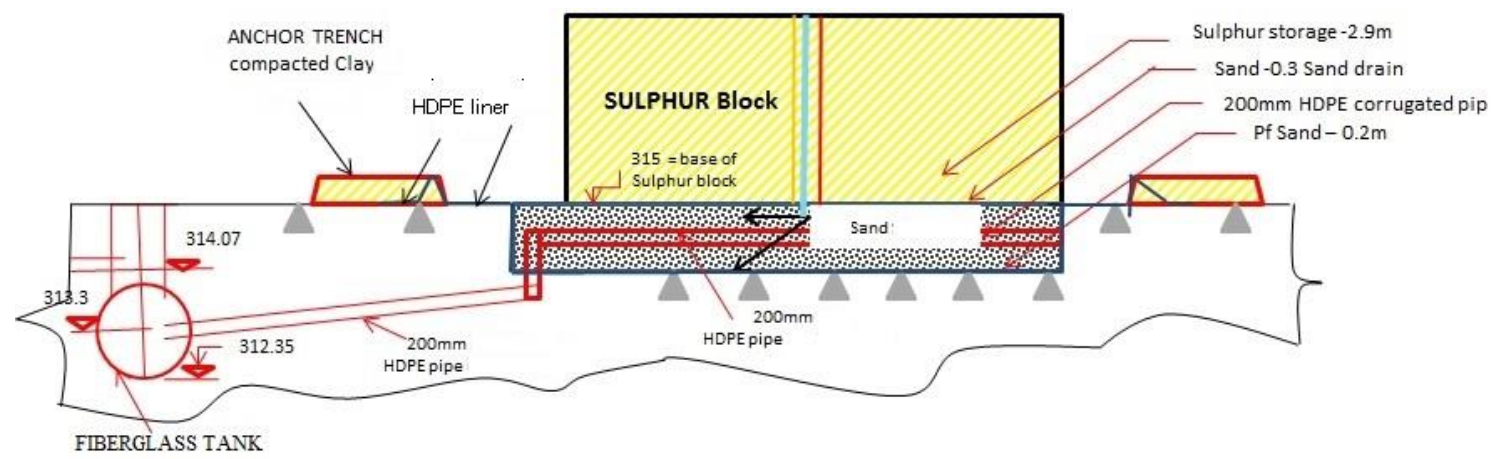

Figure 1. Cross section of Exposed Sulphur Pilot Block

Exposed Sulphur Pilot Block: The objective of the Exposed Block was to monitor on a small, measurable scale a "worst case end-member" with respect to the volume of acid produced from $\mathrm{S}^{0}$ exposed to all environmental conditions (i.e. meteoric water and oxygen, as well as temperature conditions). This was accomplished by constructing a $0.5 \mathrm{~m}$ high berm and anchor trench to surround the block at a distance of approximately $2 \mathrm{~m}$ to contain seepage from the Exposed Block. In addition, the HDPE liner extends from the block and ties into the berm to ensure seepage is contained. There was no cover system on this block. The anticipated performance of the Exposed Block was that a significant percentage of annual precipitation will report to the seepage collection system, and be acidified. The phreatic surface will likely remain in the sand underdrain. Temperatures in the block will fluctuate seasonally, and $\left[\mathrm{O}_{2}\right]$ in the block will be less than atmospheric concentrations, but not negligible. The performance was expected to be similar to the existing exposed above ground commercial scale blocks.

Insulated Sulphur Pilot Block: The objective of the Insulated Block was to determine the benefits of a thick permeable cover in maintaining the underlying $\mathrm{S}^{0}$ material below $5^{\circ} \mathrm{C}$, thereby reducing biological activity and oxidation, and thus reducing acid production. The side slopes were constructed of compacted clay, with $0.8 \mathrm{~m}$ of sand placed on the clay, overlain by $0.2 \mathrm{~m}$ of peat material. The cover system over the $\mathrm{S}^{0}$ consists of $5 \mathrm{~m}$ of sand, overlain by a thin layer of gravel to minimize dust and erosion. In addition $\left[\mathrm{O}_{2}\right]$ in the underlying $\mathrm{S}^{0}$ was expected to be near atmospheric conditions, depending on the geochemical and biological oxygen consumption in the overlying cover material. It was anticipated that in situ temperatures would decrease to below $5^{\circ} \mathrm{C}$ within a few years after placement of cover material, and remain around $3^{\circ} \mathrm{C}$. These temperatures were expected to limit biological activity, and thus biological oxidation and acid production.

Saturated Sulphur Pilot Block: The objective of the Saturated Block was to minimize the ingress of atmospheric oxygen to the underlying $S^{0}$ material by maintaining a "water cover" above the block, and thus maintain saturated conditions within the $S^{0}$. Minimizing oxygen ingress would minimize oxygen available for $S^{0}$ oxidation, and thereby control the production of acid. Temperature 
conditions within the Saturated Block were anticipated to be strongly attenuated throughout the year due to saturated conditions. The side slopes consist of compacted clay. The top of the Saturated Pilot Block is flat and also has berms at each crest in order to capture as much precipitation as possible. The side slopes of the Saturated Pilot Block were capped with $0.8 \mathrm{~m}$ of sand overlain with $0.2 \mathrm{~m}$ of peat. The cover system for the top of the Saturated Pilot Block consists of $1.5 \mathrm{~m}$ of sand, with a thin layer of gravel placed at the surface to minimize dust and erosion.

The anticipated performance of the Saturated Block cover was for a slight net deficit in the water balance, although net percolation rates would be relatively high. Oxygen concentrations in the block were anticipated to be low as a result of the saturated conditions. Temperature conditions within the Saturated Block were expected to fluctuate seasonally with little to no measurable acidity in porewater.

\section{Data Collection}

The access was provided for instrumentation at the center of the pilot blocks. Temperature profile within the pilot blocks were obtained from thermistors vertically installed at various depths within the $S^{0}$ blocks. Temperatures were logged in Data Dolphin dataloggers (Optimum Instruments Inc., Edmonton, Alberta, Canada). Pore-gas $\left[\mathrm{O}_{2}\right]$ was measured by using gas chromatography on samples in gastight, crimp-sealed serum bottles collected on nine occasions over a period of three years. The volume of drainage water was assessed by doing a water balance.
Meteorological data (rainfall, snowfall survey, potential evaporation (PE), and atmospheric temperature) from the meteorological station at the pilot blocks was downloaded from the SCL Watershed Research Database. Rainfall data from the Phase $2 S^{0}$ block (at the SCL Mildred Lake site) or Environment Canada Mildred Lake data were used if rainfall data was missing.

Drainage water in the underground storage tanks for the Exposed and Insulated blocks was sampled on 51 occasions. Prior to sampling, existing water was pumped from the storage tanks. Samples were then collected from drainage water that flowed into the tanks after purging. Samples were analyzed for $\mathrm{pH}$ and $\mathrm{SO}_{4}$ by following strandard procedures (APHA, 2005).

\section{Results}

\section{Temperature}

The temporal temperature trends of the Exposed Block for the three consecutive years and six months are shown in Figure 2. Once the residual heat from block construction was diminished, the annual trends in temperature in Exposed $S^{0}$ Block were consistent with time. The peaks in temperatures were found for the months of May to July while the lows corresponded to January to March for the each year. Temperature fluctuations were found to be maximum near the surface while at a depth of $2.42 \mathrm{~m}$ and $3.12 \mathrm{~m}$ below the surface, the temperature remained constant. The response of temperature in the blocks to change in atmospheric temperature was delayed with increasing cover thickness.

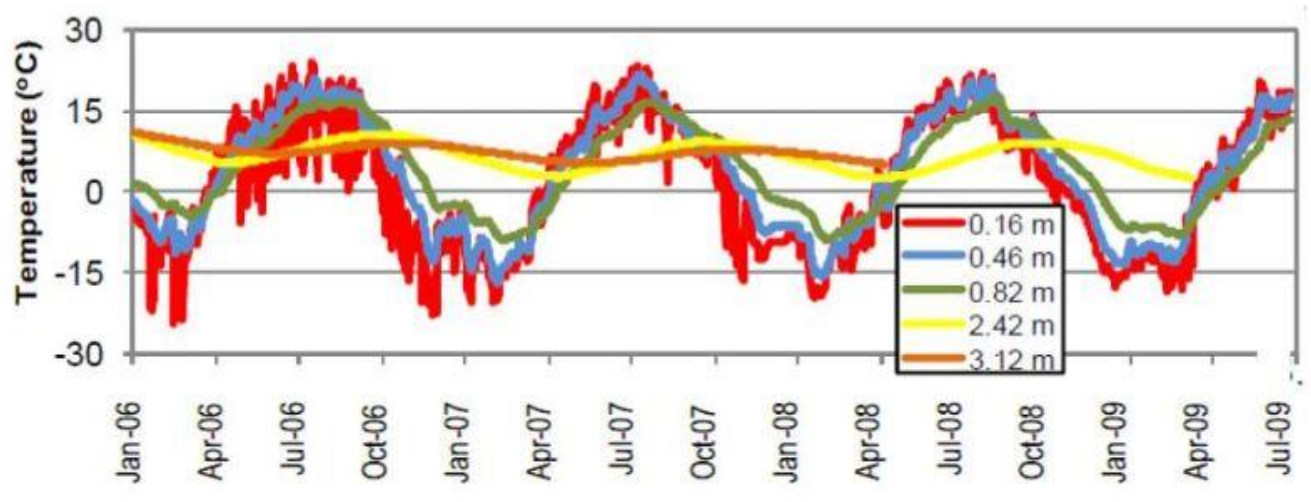

Figure 2. Temporal trend in temperature of Exposed Block
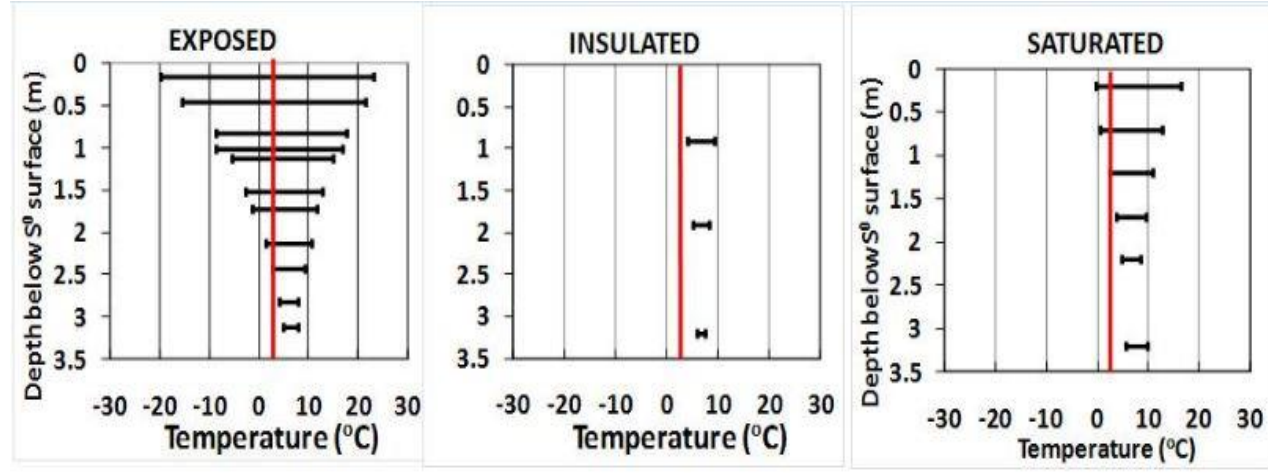

Figure 3. Temperature profile with depth of Exposed, Insulated and Saturated blocks 
Figure 3 shows temperature profile with depth for the pilot blocks. The horizontal bars show range of temperature with depth for the Exposed, Saturated and Insulated blocks. Red vertical line in Figure 3 shows the lower limit of temperature below which the oxidation of $S^{\circ}$ is neglible. Temperature variations decreased with increasing depth, and were greatest in the Exposed Block and smallest in the Insulated Block. Although complete temperature profile with depth for the Insulated Block was not obtained due to the malfunction of thermistor probes, a general decrease in depth can still be seen in Figure 3. Temperatures in Insulated Block were high enough for $\mathrm{S}^{0}$ oxidation to occur at a measureable rate. Birkham et al. (2010) measured $S^{0}$ oxidation rates in laboratory experiments at temperatures as low as $2.9^{\circ} \mathrm{C}$, therefore temperatures in the Insulated Block $\left(>3^{\circ} \mathrm{C}\right)$ are not likely low enough to maintain negligible $\mathrm{S}^{0}$ oxidation rates in the Insulated Block. In the Exposed Block, seasonal temperature variations were below the oxidation limit for approximately six months of the year. Comparatively, maximum temperatures in the Insulated Block were relatively low (e.g. maximum temperature $<10^{\circ} \mathrm{C}$ at $0.9 \mathrm{~m}$ below the $\mathrm{S}^{0}$ surface). However, the insulating cover did not allow minimum block temperatures to decrease below $3^{\circ} \mathrm{C}$ (at $0.9 \mathrm{~m}$ below $\mathrm{S}^{0}$ surface).

Temperatures in the upper $1.5 \mathrm{~m}$ of the Exposed Pilot Block and Phase 1 block were found to be similar. Temperatures at depths greater than $1.5 \mathrm{~m}$ in the Exposed Pilot Block, however, were substantially less than measured in the Phase 1 block. For example, temperatures at a depth of $2.82 \mathrm{~m}$ in the Exposed Pilot Block (after June 2007) ranged from $4.1-7.9^{\circ} \mathrm{C}$, compared to a temperature range of 10.7 - $19^{\circ} \mathrm{C}$ at depths of 3.3-3.5 $\mathrm{m}$ in the Phase $1 \mathrm{SO}$ block. Even considering the relatively poor accuracy of the thermistors in the Phase 1 block $\left( \pm 3^{\circ} \mathrm{C}\right)$, temperatures at 3.3-3.5 $\mathrm{m}$ in the Phase 1 block were $3.6-8.1^{\circ} \mathrm{C}$ greater than the Exposed Block temperatures at a depth of $2.82 \mathrm{~m}$. One possible explanation for cooler temperatures at depths greater than $1.5 \mathrm{~m}$ in the Exposed Block is a lack of lateral thermal insulation due to its smaller dimensions.

To test whether the pilot blocks can serve as an analogue to the commercial scale blocks and whether the thermal regime is similar to commercial scale block, temperatures of Exposed Block were compared with the commercial scale block temperatures (Figure 4).

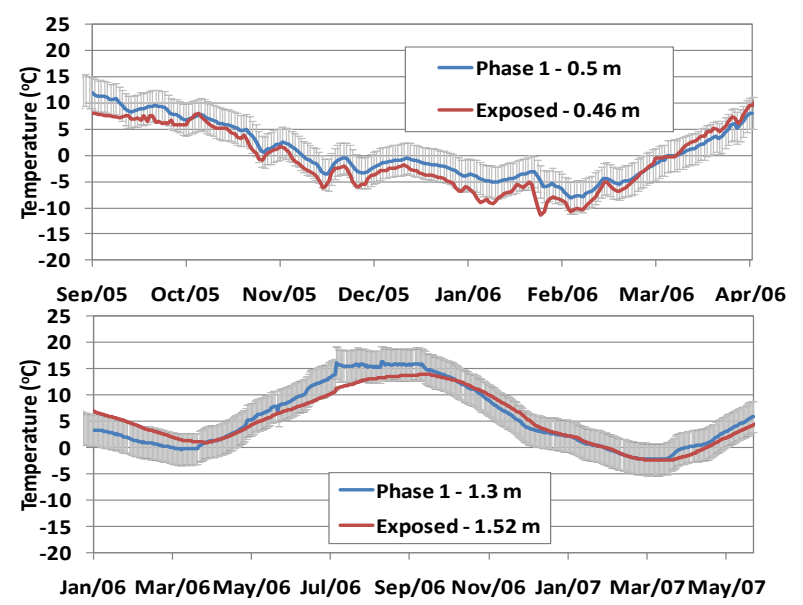

Figure 4. Comparison of temperature of Exposed and commercial scale blocks (Phase 1)
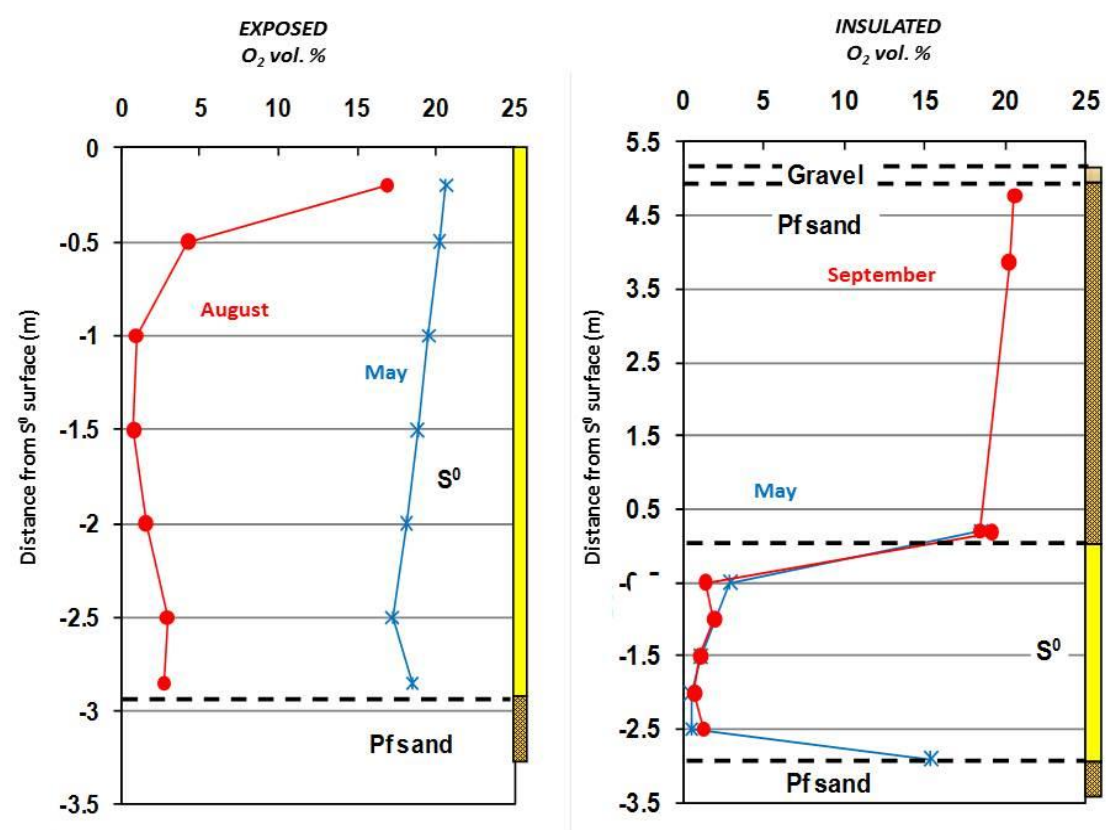

Figure 5. Oxygen profile of Exposed and Insulated blocks

\section{Oxygen}

Depth profiles of $\mathrm{O}_{2}$ concentrations $\left(\left[\mathrm{O}_{2}\right]\right)$ for the pilot blocks are presented in Figure 5 . Decreasing $\left[\mathrm{O}_{2}\right]$ in the upper $1 \mathrm{~m}$ of the Exposed and Insulated blocks suggests that $\left[\mathrm{O}_{2}\right]$ was being consumed, and as a result, $\mathrm{H}_{2} \mathrm{SO}_{4}$ produced, within each of these blocks. Increasing [02] with depth at the bottom of Exposed and Insulated blocks was observed on several occasions (e.g., May profiles). This is 
attributed to atmospheric $\mathrm{O}_{2}$ influx through the drainage pipe at the base of the blocks in the beginning of summer season.

The Saturated Block was not kept fully saturated throughout the year especially during the summer months. A complete data set for [02] was not available but temperature profile data provided reasonable picture about the production of acid within the Saturated Block. Also, bacterial growth was observed on the Saturated Block because of the partially saturated conditions. For that reason, Alberta Sulphur Research Ltd. (ASRL) concluded that if sulphur is buried, it should be kept isolated from groundwater (Paul Davis, personal communication, ASRL Calgary, Alberta, Canada). For the Exposed Block, variations in $\left[\mathrm{O}_{2}\right]$ with time were a function of temperature with $\left[\mathrm{O}_{2}\right]$ decreasing in response to increased temperature.

\section{Environmental loadings}

Environmental loadings as a result of $S^{0}$ oxidation was estimated by conducting a water balance and chemical analysis of percolate for the Exposed and Insulated blocks. Annual rainfall, average and maximum daily rainfall (for days when rainfall occurred), potential evaporation (PE) for 2006-2008, and snow water equivalent for the Insulated Block are presented in Table 1 . Snow water equivalent was not measured for the Exposed Block but is assumed to be similar to the Insulated Block as neither the Exposed Block nor Insulated Block had vegetative cover (i.e. similar capacity to trap and accumulate snow).

The drainage volume was determined by comparing the data with the studies carried out at commercial scale blocks. Birkham et al. (2011) determined that 91\% of precipitation infiltrated and rapidly drained from the Phase 1 block. Hydraulic conductivity of the Phase 1 block was estimated to range from $1 \times 10^{-1}$ to $1 \times 10^{-3} \mathrm{~m} / \mathrm{s}$, similar to a gravel or clean sand. Assuming the Exposed Block has similar hydraulic properties as Phase 1 block, drainage volumes from the Exposed Block could conservatively be estimated to be equal to the precipitation multiplied by the top surface area for the Exposed Block (453.7 $\mathrm{m}^{2}$ ). Estimates of drainage volumes for average and maximum daily rainfall, and annual drainage volume estimates for 2006-2008 are presented in Table 2.

Table 1. Rainfall and potential evaporation (PE) summary for 2006-2008

\begin{tabular}{cccccc}
\hline Year & $\begin{array}{c}\text { Annual Rainfall } \\
(\mathbf{m m})\end{array}$ & $\begin{array}{c}\text { Snow water } \\
\text { equivalent }(\mathbf{m m})\end{array}$ & PE (mm) & $\begin{array}{c}\text { Average Rainfall } \\
\text { event }(\mathbf{m m})^{*}\end{array}$ & $\begin{array}{c}\text { Maximum daily } \\
\text { rainfall }(\mathbf{m m})^{*}\end{array}$ \\
\hline 2006 & 287.1 & $\mathrm{n} / \mathrm{a}$ & 708 & 4.7 & 42.7 \\
\hline 2007 & 207.0 & 38 & 676 & 2.8 & 25.2 \\
\hline 2008 & 258.8 & 57 & 670 & 4.4 & 23.1 \\
\hline
\end{tabular}

${ }^{*}$ For days with rainfall

Table 2. Estimated drainage volumes and the chemistry for Exposed and Insulated Pilot Blocks.

\begin{tabular}{|c|c|c|c|c|c|c|c|c|c|}
\hline \multirow[t]{2}{*}{ Year } & \multirow{2}{*}{$\begin{array}{l}\text { Estimated } \\
\text { Drainage } \\
\text { volume for avg: } \\
\text { daily rainfall (L) }\end{array}$} & \multirow{2}{*}{$\begin{array}{l}\text { Estimated } \\
\text { drainage } \\
\text { volume for } \\
\text { max daily } \\
\text { rainfall (L) }\end{array}$} & \multirow[t]{2}{*}{$\begin{array}{c}\text { Annual } \\
\text { drainage } \\
\text { volume (L) }\end{array}$} & \multicolumn{2}{|c|}{$\mathrm{pH}$} & \multicolumn{2}{|c|}{$\begin{array}{c}\text { Exposed block } \\
\mathrm{SO}_{4} \\
(\mathrm{mg} / \mathrm{L})\end{array}$} & \multicolumn{2}{|c|}{$\begin{array}{c}\text { Insulated block } \\
\mathrm{SO}_{4} \\
(\mathrm{mg} / \mathrm{L})\end{array}$} \\
\hline & & & & Min & Max & Min & Max & Min & Max \\
\hline 2006 & 2,110 & 19,373 & $143.868^{*}$ & 6.5 & 7.4 & 1,950 & 3,000 & 1,950 & 2,050 \\
\hline 2007 & 1,270 & 11,433 & 111,156 & 6.5 & 7.3 & 3,000 & 4,100 & 2,100 & 2,400 \\
\hline 2008 & 1,996 & 10,480 & 143,278 & 6.6 & 7.5 & 3,500 & 4,000 & 2,100 & 2,300 \\
\hline
\end{tabular}

${ }^{*}$ snow water equivalent not measured, assumed to be $30 \mathrm{~mm}$.

$\mathrm{pH}$ and the concentration of $\mathrm{SO}_{4}$ were measured for the Exposed and Insulated blocks on the percolate (Table 2). The $\mathrm{pH}$ of drainage from both the blocks was near neutral (6.5-7.5), which might be interpreted to mean negligible $\mathrm{H}_{2} \mathrm{SO}_{4}$ production was occurring in the blocks. However, increased $\left[\mathrm{SO}_{4}\right]$ in drainage water suggests $\mathrm{H}_{2} \mathrm{SO}_{4}$ production was occurring and a buffering process was maintaining $\mathrm{pH}$ of drainage water at near-neutral values. It is reasonable to assume that acid buffering occurred in the sand underdrains given the purity of the blocks $\left(>99.8 \% \mathrm{~S}^{0}\right)$ and the hydrophobic character of $\mathrm{S}^{0}$. The mean Total Inorganic Carbon (TIC) was measured on sand samples from the Insulated and Saturated Block covers. TIC was found to be 0.13 wt.\% ( $n=6$, s.d. $=0.05 \%$ ) suggesting the presence of carbonate minerals in the sand.

Total mass fluxes of $\mathrm{SO}_{4}$, were greatest for the Exposed Block followed by the Insulated Block. Year 1 showed lower concentrations as compared to the following two years for both the blocks. The variation in the mass fluxes of
Exposed Block was much higher than the Insulated Block. The maximum fluxes corresponding to high temperature months while Insulated Block kept the temperature low year-round. As a result, estimated annual $\mathrm{H}_{2} \mathrm{SO}_{4}$ production was slightly less than the Exposed Block despite the fact that the total drainage volume from the Exposed and Insulated Blocks were equal.

\section{Conclusion}

The analysis of $\mathrm{S}^{0}$ pilot block data and the comparison with commercial scale blocks indicates that the pilot blocks will likely serve as useful analogues to commercial-scale blocks. The role of temperature and the availability of oxygen on the environmental loadings as a result of $S^{\circ}$ oxidation were evaluated. Temperature in the Exposed Block was significantly higher than the lower limit of $S^{\circ}$ oxidation process in the upper reaches of $\mathrm{S}^{\circ}$. Although cover material helped in decreasing the temperatures much lower than the Exposed Block, thickness of the covers were not 
effective in lowering the temperature below the lower limit of oxidation. The $\left[\mathrm{O}_{2}\right]$ depth profiles indicated that the majority of $\mathrm{H}_{2} \mathrm{SO}_{4}$ production in the pilot blocks was limited to the upper $1 \mathrm{~m}$, similar to the Phase 1 block.

The concentration of $\mathrm{SO}_{4}$ was used to measure the $\mathrm{H}_{2} \mathrm{SO}_{4}$ production rates. In the Exposed Block, seasonal temperature variation limited $\mathrm{H}_{2} \mathrm{SO}_{4}$ production to approximately six months of the year. Comparatively, maximum temperatures and $\mathrm{H}_{2} \mathrm{SO}_{4}$ production rates in the Insulated Block were relatively low. However, the insulating cover did not allow minimum block temperatures to decrease below $3^{\circ} \mathrm{C}$ and thereby sustained year-round $\mathrm{H}_{2} \mathrm{SO}_{4}$ production. Based on the analysis of the temperature and the availability of oxygen, it is concluded that the Insulated and Saturated covers were marginally effective barriers in controlling the oxidation of $\mathrm{S}^{0}$. As a result, environmental loadings would remain a concern for the above ground sulphur storage sites.

\section{Acknowledgements}

The author wishes to thank Tyler Birkham and Lynne Barlow for help in data collection and analysis. Thanks are also due to the author's previous employer Syncrude Canada Ltd. and Khalil Rahman of King Abdulaziz University, Jeddah, Saudi Arabia for drafting the figures.

\section{References}

APHA, 2005, Standard methods for the examination of water and wastewater, 21st edn.: American Public Health Association, Washington, DC.

Birkham T.K., Hendry M.J., Barbour S.L., Carey S.K., Lawrence J.R. and Lewko R. (2011), Water flow and storage in fractured, unsaturated sulfur blocks, Canadian Geotechnical Journal, 48, 810-825.

Birkham T.K, Hendry M.J., Barbour S.L. and Lawrence J.R. (2010), Controls and rates of acid production in commercial scale sulfur blocks, Journal of Environmental Quality, 39(3), 834-844.

Bonstrom K., 2007, Physical controls on water migration in elemental sulfur blocks, M.Sc thesis, Department of Geological Science, University of Saskatchewan, Saskatoon, SK.

Duissenov D, 2012, Production and processing of high sulphur crude and associated gases, TPG4510 Petroleum production specialization project (NTNU), 45p.

Janzen H. and Bettany J. (1987), Measurement of sulfur oxidation in soils, Canadian Journal of Soil Science, 143(6), 91-103.

Janzen, H.H. 1984, Sulfur nutrition of rapessed, Ph.D. diss, University of Saskatchewan, Saskatoon, Saskatchewan, Canada.

Laishley E., Bryant R. and Hynes J. 1985, The effect of temperature and biocides on the sulphur oxidizing activity of Thiobacilli, Alberta Sulphur Research Council. Calgary, $A B$.

Lloyd M., 1967, Oxygen-18 Composition of Oceanic sulfate, Science, 156, 1228-1231.

Ober J.A. 2000. Sulfur. U.S. Geological Survey Minerals Yearbook. 2000: 76.1-76.14.

Payzant J.D., Motgomery D.S. and Strausz O.P. (1986), Sulfides in petroleum, Org Geochem, 357-9.

Slaton N., Norman R. and Glamour J., 2001, Oxidation rates of commercial elemental sulfur products applied to an alkaline silt loam from Arkansas, Soil Science Society of America 65, 239-243.

Speight JG, Handbook of Petroleum product analysis, New Jersey; John Willey and Sons; 2002. 